\title{
Grassroots struggle: The representation of the black voice in Maishe Maponya's The Hungry Earth (1980)
}

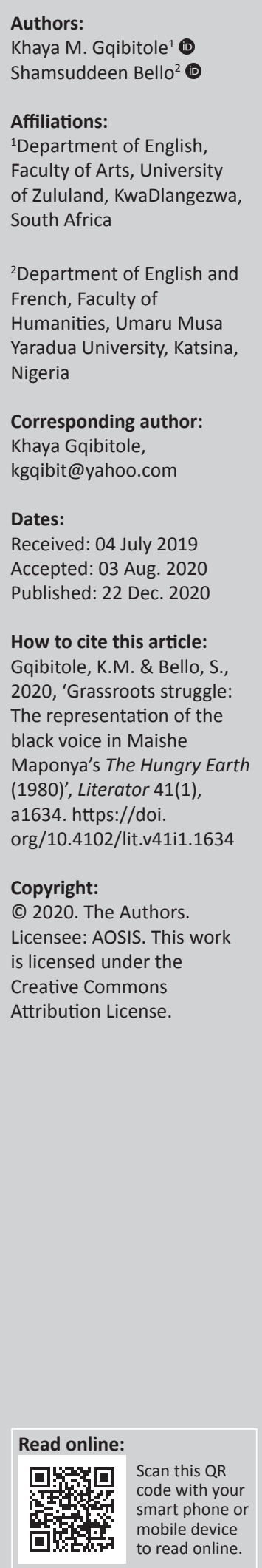

Maishe Maponya is regarded as one of the pre-eminent, militant and critical voices of South African theatre. He was not only active in the black people's struggle but also a committed playwright. To him, identity and belonging were inseparable in his quest for total liberation of the black people. Even commentators who often viewed his work as too radical and less creative could not silence the voice of the masses in his productions. Importantly, his productions not only spoke against the oppression of the black people, but also survived the draconian laws of the apartheid era. As Silber noted in 1984, Maponya and his group used the theatre of the struggle to conscientise their audiences about the socioeconomic conditions of their people. This article explores how Maponya used theatre to subvert the state and echo the travails of black people during apartheid in one of his plays, The Hungry Earth (1980). This article argues that the play is based on the people and their struggles - a clear indication that Maponya consciously articulated the hopes, dreams and frustrations of the people. The article also acknowledges the influence of Biko's Black Consciousness Movement (BCM) on Maponya's unflinching 'call to cultural arms' against apartheid, regardless of the lurking dangers.

Keywords: Maishe Maponya; apartheid; Black Consciousness Movement; militant; conscientisation; The Hungry Earth.

\section{Introduction}

Maponya's name is synonymous with the Black Consciousness Movement (BCM) because of how BCM ideals influenced and shaped his thoughts and productions. His friend, Steve Biko (the father of BCM), instilled a sense of pride and self-belief in him and other black people; hence, this politico-cultural movement popularised the idea that 'all the oppressed share an inalienable common blackness, and were in that sense black' (Buntman 2004:3). The black people had a task to free themselves from the clutches of apartheid. Maponya's theatre was imbued with this sense of urgency and black consciousness which, as Kruger (2013:9) notes, notably drew its inspiration from 'international trends derived from communism, socialism, and Ghandian civil obedience in the early period ... American black power movements and postcolonial African states formations in the later'. The resolution of Maponya and his contemporaries was to organise, enlighten and influence the poor in their fight against the oppressive system that suppressed and dispossessed them of their lands and riches. In other words, they used theatre as a political and ideological tool against apartheid; hence, their work touched many aspects of black life: from racism to exclusion, ethnicity to culture and civil rights to black political power. Having emerged in the 1960s, by the 1970s and 1980s, black theatre 'was concerned with little else than the all-consuming call to cultural arms' and The Hungry Earth was conceived under such an epoch-setting period (Opperman 1993:16). By associating himself with the struggles of the black masses, not only does Maponya share his own experiences in his plays, but he also invites the suffering masses into his productions and thus blurs the line between the productions and the lived lives of the poor. ${ }^{1}$

\section{Theatre-making, suppression and survival during apartheid}

The Hungry Earth is arguably one of the most radical, indicting and outspoken anti-apartheid plays to have come out of Southern Africa. ${ }^{2}$ Its representation project follows a black reorientation drive in the footsteps of Biko and the BCM. Maponya overcame stiff laws and trappings that would have hampered the play's production, or even limited his scope. His ardent resolve 1.The idea of identity and belonging is dealt with later.

2.Some notable radical plays before then include Kente's How Long? I Believe, Too Late, and Rev. Maqina's Give Us This Day. 
propelled his work in theatre and allowed him to transform adverse limitations and restrictions to his advantage. For instance, The Hungry Earth was first performed on a makeshift, impoverished and improvised stage - the Donaldson Orlando Community Centre - in 1979. Ironically, whilst Maponya refused to taint his voice by collaborating with white theatre practitioners who could have assisted him financially, performing in such poor venues and conditions was influenced by the works and theorisations of whites such as Beck (1972), Brecht (1964), Brook (1968) and Grotowsky (1968). Even then, he managed to use the strategies developed by these practitioners and theorists to create distinctly South African plays that were replete with black pain and suffering, thereby cementing his signature as a committed artist. Consequently, the poor were able to identify with his productions because they dealt with black people's concerns and spoke in their language. However, as the plight of the poor and the marginalised is universal, his theatre was also welcomed and understood beyond the borders of South Africa. So, despite the dangers he courted for the production of the The Hungry Earth, he took his message overseas, where the voice of the ordinary people was amplified.

Maponya was a poet before his career as a recognised and acclaimed playwright took off, ${ }^{3}$ and his embryonic stage as a dramatist started in 1975, before the Soweto Uprising and the arrest of Biko in 1976 and 1977, respectively. In 1976, he founded the Bahumutsi ${ }^{4}$ Drama Group (a troupe he directed and acted in) with the goal of reaching out to people and reeducating and re-directing them to the cause for liberation. He conceived the idea of The Hungry Earth with the Bahumutsi Drama Group in 1978. It was experimented with and first presented at the Moravian Church Hall in Diepkloof, despite the security issues involved (Maponya 1995:ii). Maponya states that the audience's reception of and response to the play - from people who were perhaps seeing a serious political play for the first time - compelled him to develop the script, which was initially a skeletal blueprint for action, informed by the need to survive and perform. It was restructured several times by the playwright, so that the complete and final version - which was first published in Stephen Gray's (1982) edition of South African Plays - was 'merely an edited scenario of quite spectacular action' (Steadman 1994:xvi).

Before then, the play remained unscripted throughout its early runs, therefore defying the conventional playwriting method that often led to censorship, banning or arrest of the artists. Subsequently, The Hungry Earth successfully toured Britain from May to August 1981 - when South African locations were literally burning - and then Switzerland and Germany. ${ }^{5}$ This feat in itself is a proof that during apartheid

3.Maponya was writing under the umbrella of the Modupe Writers Association, which was banned in October 1977. He also co-founded the Allah poets - a group of performance poets who performed in the black townships in 1978.

4. Bahumutsi means 'comforters'. Maponya saw his role (and that of the group as well) as both a messenger and comforter of the oppressed class.

5.It was performed at universities, community centres and fringe theatres and at the Edinburgh Festival and was praised as a masterpiece, experimental hit and a theatrical miracle. some black artists could make it into the world stages and, most importantly, get the voices of the poor heard. Maponya's Bahumutsi Drama Group, like many other drama groups in the country, had to contend with restrictions that were designed to silence their anti-apartheid voices. Despite the constraint that Maponya faced, which included (not limited though to) lack of finances, his repugnance of the apartheid system kept him focused on fighting it. ${ }^{6}$ Notwithstanding the financial constraints, he would not take the easy way out by collaborating with non-committed white artists. Because of the financial constraints, he was compelled to reduce the cast for the play from the original five actors to three - Maishe Maponya, Dijo Tjabane and Sydwell Yola - during the British tour and finance it himself.

It is clear that Maponya defied both state restrictions and theatrical conventions of the period in the production of The Hungry Earth. In the play, the characters are presented as part of the resistance, who - along with the playwright - throw stones at and indict the regime at every turn. As in Simon, Mtwa and Ngema's Woza Albert!, the play revisits the history of the anti-apartheid struggle by representing significant events through the eyes of black victims. The Hungry Earth and Woza Albert! are thus black accounts of events that mainly occurred in the burning townships. The plays utilised the Brechtian and Grotowskian models in 'representing social relations that revealed the contractedness of political subjectivity' (Mngadi 1996:202). The Hungry Earth, for example, offers victims' accounts of the effects of apartheid and its structure of capitalist exploitation of the poor. It is replete with significant historical events such as the colonial period and Isandlwana (Anglo-Zulu War). ${ }^{7}$ The play unapologetically and explicitly condemns apartheid and leaves no doubt as to who is to blame for the situation depicted (Koneczniak 2012). It also traces the pattern of the colonialisation process from the exploration of the land, exploitation of natural resources, and return to the colonial metropole, with the coloniser's army left behind so as to maintain the white men's authority over the new land.

\section{The oppression of black people during apartheid}

The Hungry Earth is a narrative and dramatisation (through short episodic scenes) of the misery and death that juxtaposes the tragedy of individual characters with the oppression of the black communities during the apartheid period. The play particularly advocates for collective action as opposed to individual resistance, which is limited and limiting, and more easily contained. The need to rally the masses was essential for the success of the struggle, although the BCM activists and artists were aware that the struggle had to start with the individual's resolve to resist for the common good

6.They transcended these constraints and had their first commercial performance in South Africa in the Laager at the Market Theatre in Johannesburg from 19 January 1982. See: Maponya (1995:2).

7.The Anglo-Zulu War of Isandlwana took place on 22 January 1879 and was the first major encounter between the British Empire and the Zulu Kingdom. The Zulus emerged victorious, although not without heavy casualties, thus hindering the first English invasion of the Zulu nation. 
of the people. The 'call' for action in the play centres around the individual, as it is the individuals who make up any collective action. The pronoun 'we' in the play is used at several points to demonstrate the collective will of the oppressed class to resist capitalist exploitation in the whiteowned mines and plantations.

The references to the mines, plantations and rural migrant labour reveal that the playwright is dealing with sociopolitical, economic and historical events. Matlhoko's account of the Carletonville miners' failed protest, which is similar to the failed Sharpeville protest of 1960 and the Marikana strike ${ }^{8}$ of August-September 2012, demonstrates the playwright's concern with revisiting actual events. Black artists at that time accorded keen emphasis on the specifics of the sufferings and aspirations of the oppressed class - the most obvious victims of the regime. Usiviko and Beshwana's enactment of the Sharpeville incident reveals the play's concern with actual (but heavily filtered) events:

USIVIKO. Hei Beshwana, not here! At the police station. Come, everybody, let us go to the police station.

BESHWANA. Let us throw stones then. We must put up a fight.

They stop him from throwing stones

USIVIKO. You are giving them a wrong impression of us. We are not violent people. And this is a peaceful demonstration. Come everybody $[\ldots]$

A procession and the burning of passbooks, with a song ...

USIVIKO. The police panicked at the sight of the massed though unarmed innocent black faces.

ALL. We were of the same frame of mind [...]

USIVIKO. And they opened fire! [mimes firing at the protesters as they fall to the ground]. I went to the funeral and was shocked to see how hungry this earth is, for it had opened to swallow the black man. Those who survived were arrested and charged with incitement to violence under the Police Safety Act [...] Someone somewhere did not understand peaceful and violent. (pp. 17-18)

Usiviko and Beshwana's account raises the issue of peaceful versus violent resistance or protest that remains ambiguous. Their accounts of the protests and eventual killings and arrests in the play are clearly one-sided and reveal the cracks in the glacial front of the parties involved. The encounter also highlights a mixture of issues, such as intent, accident, misinterpretation and omission (Foster, Haupt \& De Beer 2005). In a new historicist reading, questions such as the intention of the perpetrators (here the security forces) involved, their prediction of the backlash and the misinterpretation of meaning down a chain of command come to the fore. The duties of the security force in any nation are to ensure compliance with state laws, contain excesses and enforce order. New historicism requires that the critic

8.The Marikana and \#Feesmustfall protests are arguably the biggest and most darin ones in the post-1994 era. The difference is that the struggles in The Hungry Earth
were against the oppressive apartheid regime, whilst Marikana and \#Feesmustfall were against the oppressive apartheid regime, whilst Marikana and \#Feesmustfal challenge the 'people's government'. Critically although, the brutality with which the strikes, especially Marikana, were dealt with is akin to the yesteryears of apartheid. So, contrary to Opperman's pronouncement that after 1990, 'Protest theatre had in one fell swoop been robbed of its primary target', may have been prematurely hopeful. The Marikana massacre is relived in 'Marikana: The Musical' (The South African State Theatre 2014). listens to both sides - the oppressor and the oppressed before establishing a link between the text and other historical elements; in this context, however, the opposing voice which is conspicuously absent.

Unlike The Hungry Earth, Fugard, in The Island (1973), allows the oppressor a rival voice through Creon - a representative of the state. In Maponya's Gangsters (1984) also, Major Whitebeard defends - however flawed - the position of the state and emphasises his duty to enforce compliance with the law. The many apartheid laws and measures deployed to check dissent are arguably high-handed, but laws as Creon in Sophocles' Antigone (1962) and The Island (1973) contends exist to preserve and protect the interest of any state. Creon and Whitebeard's arguments suggest that their actions are in the best interest of the states they represent. They - like the other unheard perpetrators in The Hungry Earth - most naturally reject their ascription or labelling as perpetrators of heinous acts. It is far more convenient for third parties - the writer, for example, as he is only re-enacting the event - to use the label 'perpetrators'. Foster et al. (2005:5) noted that the Truth and Reconciliation Commission (TRC) hearings reveal that it is 'easier for outsiders, observers, analysts, and reporters to wield the term than for actors and agents of the deeds, whether individually or collectively, themselves to own the label'.

The representation of events in The Hungry Earth is not only simplistic, and often unjustified, but also unapologetic and bitter. The play adopts a black voice and, most importantly, politics as its sole dimension. The image of the clenched fist raised high in a black power salute and the emphasis on collective action qualifies it as radical and political in BCM terms. This icon of the clenched fist represents black power and unity in both arts and politics. It also generated open participation in the early performances of the play. Schechner's participation rule (Innes 1993) states that audience participation can alter the nature of a performance - its rhythm and outcome. The black audiences, for whom the play was primarily intended for, usually reacted with the same thrust and anger whenever the clenched fist image was used during the performances. ${ }^{9}$ The image still generates similar reactions amongst the black people during protests and performances in South Africa.

\section{Struggle songs and lamentations}

Black resistance forms the backdrop for the action in The Hungry Earth. The resistance songs in the play aid in the call for the black people to reflect, rise up and resist imperialism and capitalism. Songs have the tendency of breaking cultural complexes and language barriers and awakening the idle, passive mind. The songs in the play are intended to stir the (once heroic) spirit of the defeated black people so that they can resist exploitation and the imposition of the apartheid state. They are also intended to rekindle the love for the land

9.Richard Schechner proposed three actor-audience participation rules. They are summarised as follows: (1) audience in a space or living situation, (2) the actors' See: Innes (1993). 
and the lost enthusiasm to defend the people and culture. The conscientisation and rallying motive is apparent in the way the songs evoke the need for Mother Afrika to wake up before she is raped, to nudge black people to rise up and end the plunder and exploitation of human and natural resources and to agitate for an end to the hungry earth's insatiable longing for black sacrifice. The agitation in the play is not watered-down and, therefore, counters adaptation, unlike in plays produced by white playwrights (alone or in collaboration), which are about the same or similar events.

The Hungry Earth condemns the silence and inaction of the oppressed black people who stand aloof despite the rape of the land. It challenges the evident lack of feeling and passion to defend the land and its people from oppressive laws. The songs query the reluctance of the oppressed to 'go into the streets and stop the wars, stop slavery, destroy the prisons, stop detentions, stop the killings, stop selfishness ...' (p. 3). The play suggests that it was individual selfishness and cowardice that led to the conspiracy of silence in the country. The need to survive and, at best, minimise trouble compelled many black people to act individually, but not because they lacked feeling. In that period, the black people were aware of the rigid police state and its containment measures. This awareness is epitomised in Buntu's conformity in Fugard's Sizwe Bansi is Dead (1972). It was a regulatory and vital determinant of the conflicting groups' (blacks and whites) action and inaction. However, the defiance songs in The Hungry Earth stress that black people will with time learn what strength, love and courage are and will unite to defend the land despite the ominous odds:

ALL. We will sing while we crawl to the mine

TWO. We will rise up

ALL. Bleeding through the days of poverty

THREE. We will fight hard

ALL. Pulsing in the hot dark ground

FOUR. We will rise up

ALL. Dying in the stubborn hungry earth, we will fight hard

ALL. We will rise up

And we will sing loud

Against the hungry earth

It is our sweat and our blood

That made Egoli what it is today. (pp. 3-4)

This song is a mixture of related issues: conscientisation (it is their sweat and blood that made Egoli/Johannesburg what it is today), rallying (we shall sing, fight and rise up) and determination (singing out against the hungry earth). It demonstrates both a rise in consciousness and a will to fight. The characters' regained feelings and urgency reflect in the collective will to fight hard and sing loud. This song also echoes the growing confidence of the proletariat and their readiness to unite to end the dehumanising living and working conditions of migrant workers. The characters' changing circumstances (finally willing to fight) reflect the turn of events in South Africa after 1976 because:
[T] he events of 16 June 1976, when black schoolchildren crystalized generations of radical discontent by turning protest into active resistance, were symptomatic of radical developments in the political and cultural relations and make that a watershed year in many ways. (Steadman 1988:24)

The change in tone from conscientisation and rallying to the need for the black people to pick up arms and fight echoes in Beshwana's call; a clear shift from protest to resistance to militancy, a transition that some playwrights, such as Fugard, failed to achieve:

BESHWANA. Stand up all ye brave of Afrika

Stand up and get to battle,

Where our brothers die in numbers

Afrika you are bewitched

But our black blood will flow

To water the tree of our freedom [...]

Mother Afrika wake up

And arm yourself,

Wipe the tears of your brave

Mother Afrika wake up,

Lest umlungu rapes you [...]. (pp. 7-8)

The reference to the mines and able-bodied rural migrant men who die in the stubborn hungry earth reveals the sad ironic reality of the situation; it is the same men who grease the capitalist wheels of the system that exploits them. The driving force was survival: Buntu in Sizwe Bansi is Dead and Jonathan in Gangsters stress this. The woman's lamentations in The Hungry Earth attest to the anomaly of black survival during apartheid: 'Oh how cruel this earth is. Our men never stop dying to feed this hungry earth' (p. 23). She is both an indirect victim of the system (as her husband died digging gold for the white man) and a symbol of other women who lost husbands, sons, brothers and fathers in the same exploitative capitalist process. Her frenzied call for the men to own up to their responsibilities is crucial because the woman in this play (and in some literature) represents a new beginning and rebirth - a dawn of a new era in the struggle. She saliently questions the very heart of the apartheid, capitalist system:

WOMAN [hysterical and crying]: Oh, how cruel this earth is. Our men never stop dying to feed this hungry earth. Today I have no place to stay. Today I am a widow. Today my children are fatherless yet I do not know. How many more have vanished like that without the knowledge of immediate relatives? My husband has died digging endlessly for gold which would help to prop up the apartheid system. My man is dead! My man is eaten by the hungry earth! He is dead! (p. 23)

The woman's lamentations raise an important existentialist question: what is the place of God in the affairs of man? Like Vladimir and Estragon in Beckett's Waiting for Godot (perf. 1950; pub. 1956), she queries the place of God who allows and watches the perpetuation of man's inhumanity on fellow men. The Hungry Earth was influenced by the absurdist 
drama and the existentialist ideals of writers such as Beckett, Camus and Sartre. This influence can be seen in the depiction of the absurdity of the characters' lives. God may be absent in the drama, but the characters have not lost the determination to resist and fight on. Unlike Fugard, Maponya tries to transcend the absurdity of the human condition by allowing his characters to rise up, unite and advocate for change in the status quo. This is exemplified in The Hungry Earth in the characters' resolution to defy the fetters of the law. The epilogue song indicts the regime and blames the capitalist system for the mass and unaccounted deaths in the mines:

Where have all our men gone

They have all gone down into the mines

They will never return again

They have been swallowed up by this hungry earth! (p. 24)

\section{History, representation and identity}

Maponya's use of allegorical characters in the play is intended to depict the state of affairs in South Africa. The characters' names, Beshwana, loincloth (suggesting black dignity, manliness and courage); Sethotho, imbecile (referring to black cowards, moles and betrayers of the struggle for freedom); Usiviko, shield (referring to the non-violent defenders of the black liberation cause); Umlungu, white colonialists (implying exploiters of the black people and their lands); Sizani, helper (meaning helping each other), and Matlhoko, suffering (depicting the oppressed and exploited black people), represent this historical period. Bearing in mind their allegorical representations, the actors recreated or restaged real experiences and the effects of the system on their lives. They equally revisited the contentious history of their people in a bid to offer the black man's account of the events. Matlhoko's narrative of arrival and conquest suggests that the history of the country did not start in $1488,{ }^{10}$ when the white people arrived at the Cape:

MATLHOKO. When this land started giving birth to ugly days, things started going wrong from the moment of dawning and peace went into exile, to become a thing of the wilderness. Yes, we experienced the saddest days of our lives when umlungu first came to these shores called Africa, a total stranger from Europe. We received him kindly. We gave him food. We gave him shelter. We adopted his ideas and his teachings. Then he told us of a god and all black faces were full of smiles. When he said love your neighbour we clapped and cheered for we had a natural love. Suddenly we drifted back suspiciously when he said you must always turn the other cheek when you are slapped. He continued to say love those who misuse you [...] And whilst we were still smiling, he set up laws, organised an army and started digging up the gold and diamonds; and by the time our poor forefathers opened their eyes, umlungu was no more - he had moved to Europe. He has only left his army behind to 'take care of the unruly elements that may provoke a revolution'. (pp. 5-6)

Matlhoko's narrative is an apt black account of the colonial patterns that led to the imposition of apartheid. His reference

10.The Cape was discovered by Bartolomeu Dias in 1488 after journeying south along the west coast of Africa, followed by Vasco da Gama in 1497. However, it is widely claimed that the San (hunter-gatherers) and the Khoi Khoi (pastoralists) have lived in Southern Africa over 2000 years. to the 'land' implies a vast area without boundary. The geography and history of what is South Africa today were 'marked by competing and often incompatible representations of the land and its people' (Kruger 2004:249). The country like perhaps all former colonies - is a product of imperial mapping. Matlhoko's claim to the land comes close to Caliban's (in Shakespeare's The Tempest) thoughts on the 'isle' as entirely his inheritance. Their accounts of the arrival of the so-called foreigner, from the pre-colonial period of relative peace, hospitality of the natives, colonial set-up to eventually domination and containment, are also similar. Ngugi traces a similar pattern in East Africa in his trilogy of Weep Not Child (1964), The River Between (1965) and A Grain of Wheat (1967).

The Hungry Earth also revisits the wars between the so-called sophisticated invaders and the brave inhabitants of the land. The play's account of what triggered the war and the bravery of the natives who stood up against an overpowering enemy is also one-sided. Beshwana speaks of the battle of spears against guns and recounts how the brave natives 'stormed the bullets to protect their motherland from the cruel Umlungu. One-two-ten hundreds of our brave never flinched, yet they knew they were heading for death' (p. 7). The emphasis is first on the love for Mother Afrika, then on the fact that this time around it is the black people who tell the story. Matlhoko's narrative of what actually happened during Isandlwana (Anglo-Zulu battle) on 22 January 1879 is apparently a one-eyed account of the events. His narrative of the Zulu victory centres the trauma of the event and the sacrifices of the natives who had to defend their land.

Southern Africa (and most early cultures and nations) was historically known for territorial conflict, inter-ethnic rivalry and wars of conquests; as such, the attempt by the Zulus during Isandlwana to defend the land was not altogether new. There are reports of several wars between the natives (Zulus and Xhosas) and the white settlers. Kruger (2004:247-248), for example, writes that, 'the Dutch (1652-1806) and the British (1806-1910) regimes in the Cape clashed with Xhosa, who competed with white settlers for farmlands ...' In most of these wars, black people bravely fought mainly with spears but lost because of the sophisticated and heavy artillery power of the white people (Cottrell 2005). The love for the land and its people had always led them to put up resistance against even superior adversaries, leading in many cases to conflicts. During the 1730s, for example, the 'Khoisan conducted extended guerrilla campaigns against the settlers, while in the 1770s, additional clashes occurred as colonial farmers drove deeper into lands occupied by the Khoisan' (Cottrell 2005:19).

It was around the 1770s that the enslaved Khoisans (adults, children and elderly) were mandated to carry passes (Cottrell 2005). The Pass Law system ensured compliance and regulated the movements of the natives. In The Hungry Earth, Usiviko speaks of how this pass system was used to enforce segregation and deny black people the right to free movement in the country: 
USIVIKO. Most of us were 'requested' to produce passes and permits. Those who failed to produce spent two weeks in jail and were deported to their respective home on their release. This is the inhuman and unjust procedure to endorse the unjust laws that make another a stranger in the land of his birth and rob him of his freedom to move wherever he wants. Is freedom not the law of nature? Then what? (p. 14)

The characters' narrations in the play reveal the personal as well as collective consequences of the pass laws on black life. Their recollections are steeped in historical events that can if need be verified (or otherwise falsified) by recourse to the varied historical accounts of apartheid. History has always been in a state of flux: ever-shifting and unstable. Plato and Reeve (1992) argued that truth is an abstract idea; hence, there is no ideal truth in the sense of something concrete and verifiable. Truth exists mostly at the level of philosophical contemplation (more in the mind) than in the real and natural world. The question of actual or objective history has thus been challenged by historiographers and new historicists. There is no truth devoid of contradiction and self-centred narration or perspective. The Hungry Earth, despite the limits of its proclaimed truth, is replete with historical claims on the effects of the capitalist system on individuals in mines, hostels, plantations and compounds. It stages black labour and experiences during apartheid, narrated through the voice of victims of the system, and yet can be as unreliable as any account of events of the period.

The liberation songs in the play demonstrate that change is possible, but only if black people can unite against the regime. The play emphasises what Maponya sees as theft, plunder and exploitation of the land and its human and material resources, and it agitates for an end to the plunder. Matlhoko speaks of these thefts:

[M]en and women of Afrika: umlungu has left us secretly. He has taken with him a great wealth of property, our sheep and our cattle, our men and women as servants, gold and silver, and all precious stones. (p. 6)

The voice of Umlungu - the white man in isiZulu - is heard this time around, allowing an opposing perspective of the events instead of the usual skewed account. However, Umlungu is only given a limited scope to assert his claims over the lands; he attempts to reject the tag of a complete foreigner and is suddenly silenced when it comes to the exploitation and claims that he has robbed the land of precious resources and human capital. The notion of a foreigner boils down to the question of national identity and cultural identity, which are problematic terms. Walder (2012) argued that how we choose to:

[I]dentify ourselves depends upon the situation in which we are called upon to do so, since in practice everyone, migrant or not, has more than one identity and even, often, more than one place to call home. (p. 57)

As in a tribunal (a clear Brechtian appropriation), Maponya presents his colonial narrative bit by bit, allowing his audience or readers to harmonise with him or arrive at a decision on the two contending histories, the colonial versus alternative black history. He also revisits the label of foreigner that has generated debates over time. Identity is a fluid construct that is negotiable. It is often enforced (also marred) by internal and constructed narratives that we tell ourselves; the:

$[P]$ rocess of knowing that can be and often has been seen as analogous to what happens in nations, the product not only of a sense of shared language, culture and territory, but crucially also of a real or ... imagined ancestry. (Walder 2012:50)

It is often our narratives that come to form our sometimesflawed sense of identity and place even as we are all foreigners and so cannot make any safe claim over a land. The nomenclature of a stranger is, therefore, subject to play, negotiated and renegotiated in the context of societal formation or acceptance. The absence of a stable centre further problematises the concepts of identity and roots. Identity, in any guise, is an unstable construct in the contemporary world. The mass movement of people across the world in the last century (and even further back) confirms that we are who we are, a people devoid of a stable ancestry or territorial claim. Walder (2012:24) corroborated that these global movements led people to ask nudging questions: 'Who am I? Where do I come from?' The question of a national identity appears to be common in post-colonial countries, 'where national identity has been a more troubled and troubling phenomenon, and far from settled or agreed' (Walder 2012:57). In The Hungry Earth, Umlungu's claim to the land and its natural resources can be somewhat justified by this contemporary movement. His sense of identity seems to defy the old debate about the politics of location.

\section{Capitalism as an apartheid wheel}

The Hungry Earth presents us with a proletariat-bourgeoisie conflict and demonstrates that it is born out of the capitalist system of division of labour, one that divides people into groups based on the manner of their production and contribution to the state. Maponya presents these antagonistic classes as dependent on each other: whilst the bourgeoisie owns and controls the mines and plantations, the proletariat services them with blood, bones and sweat. This is what Karl Marx in Das Capital (1867) ${ }^{11}$ calls surplus value of labour. It is for this reason that the protesting miners at Carletonville (discussed earlier) were forced to return to work. The black workers, during apartheid, sold their labour to white people in order to make ends meet. This can be seen in the play in how the three child workers at the Doringkop plantation label the Visitor (who doubles as investigator) as a troublemaker. The majority of the black labourers at the plantation regard their work there as the only available option; yet, to white people, they seem willing to serve in return for a pittance or a place to live in the stables. Plantation work is the surest option (at least better than mining) in their pitiful existence, and they must sell their dignity for a little pay. The Hungry Earth presents that, despite the piteous work 11.The book was a critique of political economy originally written and published in 1867 and edited by Friedrich Engels. 
and living conditions of the labourers at the plantation, they are still better off than the miners at Carletonville considering the risk and labour involved.

The characters in The Hungry Earth challenged black conditions at the mines and plantations. Usiviko accuses Umlungu of exploiting black labour: 'you underpaid us and celebrated when we were starving' (p. 7). He also accuses him of dubiously extorting the natives who exchanged their cattle and sheep for mere mirrors and knives and for stealing from the land and using black labourers to till the same land. The characters narrate how the Transkei child labourers are exploited at the Doringkop plantation (a microcosm of other plantations across the nation) by being housed in stables and badly fed, with no lunch at all. These workers have to trek for 6 miles every day to the sugar field. It is revealed in the play that whilst the young boys earn just mere cents, the adults earn a few rands, not more than 2 rands daily for tedious work. The Visitor narrates that, 'some women told me they earned R1,10 a day and some men said they earned R2 a day after working nine hours' (p. 10).

Capitalism utilises and exploits human capital. Illovo (the reported owner of the plantation) is a typical example of the bourgeoisie who bask in comfort at the expense of the arduous work of the largely malnourished and exploited labourers. Maponya demonstrates an awareness of the capitalist benefits of imperialism. The references to the Carletonville mine and Doringkop plantation confirm that he understands the workings of the imperialist and capitalist process, whereby one group lives in comfort because the others suffer. The conditions of life in plantations around the world - Kenya, America and Antigua, for example - were the same. The owners of the plantations, more or less, feed off human labour. In Mansfield Park (1814), Jane Austen depicted an Antiguan sugar plantation as the source of comfort for its owner and misery for the labourers (Said 1993; Webster 1996).

Maponya questions the values and principles of the imperialist-capitalist system and attempts to turn the tide around through education, mass rallying and militant action. He also criticises the public morale and the passive (and silent) acceptance of this system; he advocates for the collective will to resist exploitation in the plantations, compounds and mines. Maponya is, however, aware of the absurdity of avoiding trouble in the country, as well as the black people's (almost) futile struggle against the regime. In Fugard's Sizwe Bansi is Dead, Buntu notes the futility of the black people's attempts to stay out of trouble or achieve anything meaningful at the time. In The Hungry Earth, Sethotho emphasises this futility whilst warning the workers in the train:

SETHOTHO. Hey, my father lived in the city of gold and he told me there are so many crimes against the law of the white man of which black people might unwittingly be guilty. You will end up in jail if you are found in the streets of the city and can't produce a pass anytime and anywhere the police demands it - even in the toilet - I tell you, they sometimes hide in there. If you drink too much you may be arrested for over-indulgence in alcohol. Do you know detention without trial? Section 10? Or six? Do you know house arrest? Do you know Robben Island? Makana? My father knows all! (p. 13)

The Hungry Earth stages the specifics of this colonial process, noting how black people were looked down upon, offered lowly (menial and domestic) jobs and branded as 'bastards' (p. 12). In the play, black people are depicted as bus drivers, labourers in plantations and miners - menial jobs that do not require an educational qualification - compared with white people, who own mines and plantations and supervise black people as they carry out the risky and arduous work. The play recounts the sacrifices of black people whose 'sweat and bones and blood [...] made Egoli what it is today' (p. 16), but who, as represented by the characters, were, ironically, never allowed to reside or work there without a permit (permits range from residence permit, hawker's license, parole permit, work-seeker's permit to lodger's permit). In the play, Chirango (the woman) narrates how she was arrested in the city because she had no permit and 'fined R90 or 90 days' (p. 23). She notes that she had to go to jail after her arrest in the city as her husband, who had written to her to join him in the city, had no money to settle the fine. Fugard also dealt with these kinds of specifics but was particularly more interested in the depth of the bits of individual experiences than Maponya, who was more into the political dimension of art than the artistic representation of events.

\section{Conclusion}

As discussed in this article, The Hungry Earth is clearly about the cause and effect of things, proving that exploitation breeds dissent. Maponya utilises the play to condemn the regulatory apartheid policies and capitalist wheel that crushes the bones of black people in the mines and plantations. He equally criticises the high-handed measures of containment that often lead to violence, deaths and arrests. It is clear in the drama that the playwright does not only recount and preserve the lived life of black people but also forcefully critiques the excesses of the apartheid system, calling on the oppressed to take action to ease their lots. His militancy is far removed from the protest works of the earlier period. Unlike some of his contemporaries, he confronted the enemy head-on. It is this blatant disregard for personal safety that sets him apart from many theatre practitioners of his time and places him at the centre of black man's struggle for total liberation through the theatre. The voices of his characters echo the voice of the poor masses; hence, the poor recognise themselves in his productions. This article reveals that Maponya's ardent voice in The Hungry Earth represents the feelings and desires of the poor who yearned for a guiding light in those dark days of apartheid. Just like the characters in the play, the poor, despite the pervasive danger that lurked around them, realised that it is through their collective action that their dignity, land and self would be restored to them. The role that BCM played as a politico-cultural movement was immeasurable in shaping both the content of the play and the events outside it. 


\section{Acknowledgements}

We acknowledge the role played by Prof. Rob Baum as the co-supervisor of Bello Shamsuddeen.

\section{Competing interests}

The authors have declared that no competing interests exist.

\section{Author's contributions}

All authors contributed equally to this work.

\section{Ethical consideration}

This article followed all ethical standards for carrying out research without direct contact with human or animal subjects.

\section{Funding information}

This research received no specific grant from any funding agency in the public, commercial or not-for-profit sectors.

\section{Data availability statement}

Data sharing is not applicable to this article as no new data were created or analysed in this study.

\section{Disclaimer}

The views and opinions expressed in this article are those of the authors and do not necessarily reflect the official policy or position of any affiliated agency of the authors.

\section{References}

Beck, J., 1972, The life of the theatre: The relation of the artist to the struggle of the people, Limelight Edition, Rochester Hills, MI.

Beckett, S., 1956, Waiting for Godot, Faber \& Faber, London.

Brecht, B., 1964, Brecht on theatre: The development of an aesthetic, transl. J. Willet, Hill \& Wang Publishers, New York, NY.
Brook, P., 1968, The empty space, Athenaeum, New York, NY.

Buntman, F.L., 2004, Robben Island and Prisoner resistance to apartheid, Cambridge University Press, Cambridge.

Cottrell, C.R., 2005, South Africa: A state of apartheid, Chelsea House Publishers, Philadelphia, PA.

Foster, D., Haupt, P. \& De Beer, M., 2005, The theatre of violence: Narratives of propaganda in the South African conflict, HSRC Press, Cape Town.

Fugard, A., 1972, 'Sizwe Bansi is dead', in D. Walder (ed.), The township plays, 1995, pp. 10-42, Oxford University Press, Oxford.

Fugard, A., 1973, 'The Island', in D. Walder (ed.), The township plays, 1995, pp. 10-42, Oxford University Press, Oxford.

Gray, S. (ed.), 1982, Athol Fugard, McGraw-Hill, Johannesburg.

Grotowsky, J., 1968, Towards a poor theatre, 4th edn., Prentice Hall, London.

Innes, C., 1993, Avant Garde theatre: 1892-1992, Routledge, London.

Koneczniak, G., 2012, 'From orality to visuality: Enactment of new-colonialism', in M. Buchholts \& G. Koneczniak (eds.), The Hungry Earth by Maishe Maponya and Ubu and the Truth Commission by Jane Tylor', in The visual and the verbal in film, literature and biography, pp. 89-115, Peter Lang, New York, NY.

Kruger, L., 2004, 'Reassembling South African theatre history', in T. Postlewait (ed.), Writing and rewriting national theatre histories, pp. 244-265, University of lowa Press, lowa City, IA.

Kruger, L., 2013, Imagining the edgy city: Writing, performing, and building Johannesburg, Oxford University Press, Oxford.

Maponya, M., 1982, 'The hungry earth', in Doing plays for a change, 1995, pp. 1-145, Witwatersrand University Press, Johannesburg.

Maponya, M., 1984, 'Gangsters', in Doing plays for a change, 1995, pp. $74-111$, Witwatersrand University Press, Johannesburg.

Maponya, M., 1995, Doing plays for a change, Witwatersrand University Press, Johannesburg.

Marx, K., 1867, Das Kapital, Verlag von Otto Meissner, Hamburg.

Mngadi, S., 1996, 'Politics of historical representation in the context of global capitalism', in J.A. Smith, J. Van Wyk \& J.P. Wade (eds.), Rethinking South African literary history, pp. 196-208, Y Press, Durban.

Opperman, D., 1993, Revolution and conscience: South African theatre, Jun 1976-Feb 1990, University of Michigan Press, Ann Arbor, MI

Plato, G.M.A. \& Reeve, C.D.C. (transl.), 1992, Republic by Plato, Hackett Publishing Company, Indianapolis, IN.

Said, E., 1993, Cultural and imperialism, Knopf, New York, NY.

Silber, G., 1984, 'Theatre of the fist', Frontline, 25 January, p. 10.

Sophocles. Antigone (transl.), 1962, Oxford world's classics, Oxford University Press, Oxford.

Steadman, I., 1988, 'Stages in the revolution: Black South African theatre since 1976', Research in African Literature 19(1), 21-42.

Steadman, I., 1994, 'The theatre of Maishe Maponya', in M. Maponya (ed.), 1995 , Doing plays for a change, pp. xii-xxiii, Witwatersrand University Press, Johannesburg.

The South African State Theatre, 2017, Marikana the musical, viewed n.d., from https://www.youtube.com/watch?v=LJoYOhl3CaA

Walder, D., 2012, Postcolonial nostalgia: Writing, representation and memory, Routledge, New York, NY.

Webster, R., 1996, Studying literary theory: An introduction, 2nd edn., Arnold, London. 